\title{
Hydrophobic Polyurethane Coating against Corrosion of Reinforced Concrete Structures Exposed to Marine Environment
}

\author{
Cecielle N. Dacuan ${ }^{1, *}$, Virgilio Y. Abellana ${ }^{1}$, Hana Astrid R. Canseco ${ }^{1}$, Minerva Q. Cañete ${ }^{2}$ \\ ${ }^{1}$ Engineering Graduate Program, School of Engineering, University of San Carlos, Philippines \\ ${ }^{2}$ College of Engineering Architecture and Technology, Palawan State University, Philippines
}

Received February 27, 2021; Revised April 6, 2021; Accepted April 29, 2021

\section{Cite This Paper in the following Citation Styles}

(a): [1] Cecielle N. Dacuan, Virgilio Y. Abellana, Hana Astrid R. Canseco, Minerva Q. Cañete, "Hydrophobic Polyurethane Coating against Corrosion of Reinforced Concrete Structures Exposed to Marine Environment," Civil Engineering and Architecture, Vol. 9, No. 3, pp. 721-736, 2021. DOI: 10.13189/cea.2021.090314.

(b): Cecielle N. Dacuan, Virgilio Y. Abellana, Hana Astrid R. Canseco, Minerva Q. Cañete (2021). Hydrophobic Polyurethane Coating against Corrosion of Reinforced Concrete Structures Exposed to Marine Environment. Civil Engineering and Architecture, 9(3), 721-736. DOI: 10.13189/cea.2021.090314.

Copyright $\mathrm{C} 2021$ by authors, all rights reserved. Authors agree that this article remains permanently open access under the terms of the Creative Commons Attribution License 4.0 International License

\begin{abstract}
The environment, in which structures are exposed influences durability performance and deterioration. The durability degradation of structural concrete located in aggressive marine environments due to corrosion is a major problem in the construction industry. Deterioration due to corrosion is associated with quantifiable losses, which is a financial burden for any developed country. The initiation of corrosion can be obviated to some extent by different methods. Hydrophobic coatings are waterproofing coatings on the external surfaces of concrete structures, which are used to combat the problem of deterioration due to corrosion and to extend the serviceability of reinforced concrete structures. Polyurethane coatings can be used to protect structural materials, particularly those exposed to corrosion, abrasion, weathering, and other processes that would help to degrade base materials over time. From the experimental study conducted, a total of 58 specimens of different descriptions were cast and subjected to several tests, including chloride permeability, chemical resistance, chloride diffusion, water absorption, and corrosion-accelerated procedures using the galvanostatic method. The results indicate that the effectiveness of polyurethane in resisting the diffusion of chloride is eight times greater than that of the base concrete specimen. It has a lower percentage weight reduction, considering acid penetration. The chloride permeability of the coated specimens was negligible, and the water
\end{abstract}

absorption was low. The crack frequency was reduced in the specimens with hydrophobic coatings. The group of specimens with hydrophobic coatings had lower corrosion rates and narrower crack openings and had less reduction in diameter. Furthermore, it takes longer for cracks to develop on the surface of the specimen with polyurethane coatings. It has a lower amount of corrosion, and it takes a longer period to accumulate a critical amount of corrosion. Thus, hydrophobic polyurethane coatings are highly effective in reducing the chloride permeability and water penetration values, which helps to eliminate corrosion and lengthen the service life of structures located in an aggressive marine environment.

Keywords Hydrophobic Coating, Polyurethane Coatings, Corrosion Resistance, Crack Widths, Crack Frequency

\section{Introduction}

Concrete is commonly used in construction owing to its versatility and mechanical properties [15]. However, its durability depends on the environmental characteristics in which it is found [10]. Almusallam et al. further affirmed that the environment in which the structures are exposed 
influences their durability performance and deterioration [2]. In addition, according to Ramesh(2014a), the deterioration of structures is associated with interactions between the materials and the environment. The mechanism of corrosion depends on the environment in which the structure is exposed [30]. Thus, the durability degradation of reinforced concrete structures located in aggressive marine environments due to corrosion is a major problem in the construction industry [21,34]. This has been of great interest to researchers and designers.

Durability, according to Balagopal et al., is the ability to resist the attack of deteriorating agents, such as corrosion and any other forms of deterioration [12]. Concrete members can be considered durable if they maintain their initial characteristics when they are subjected to extremely harsh environments, such as acid, chloride, and sulfate environments [31].

Concrete is generally made with a mixture of Portland cement and alkaline potable water $[11,23]$. On the other hand, marine water typically has several chemical, mining, and deleterious substances with high acidity [4, 24]. Owing to the high alkalinity of concrete with ordinary Portland cement, it is susceptible to chloride and sulfuric attack from the atmosphere and marine environment $[9,25]$. The acid attacks the embedded reinforcing steel through chloride diffusion [11]. Therefore, the corrosion of steel is initiated when the diffused chloride that accumulates at the reinforcement level reaches the threshold limit, and the passive film formed over the steel surface is altered $[28,32$, 39].

The initiation of corrosion can be obviated by different methods, such as protective coating on the concrete surface, improving the quality of mixtures, increasing its concrete cover thickness, using corrosion inhibitors, and cathodic protection of the surface. Among the different protective methods, adhesive coating with durable properties is considered the most cost-effective and feasible option for economic and technical reasons $[2,32]$.

Protection of reinforced concrete structures, particularly those exposed to marine environments against deterioration due to corrosion by using organic coatings is an area of great interest [14]. The application of a suitable protective coating improves the durability of structures, even under aggressive exposure [16]. Organic coatings improve the corrosion resistance and extend the serviceability of reinforced concrete structures [14].

Several types of concrete coatings have been commercialized for the protection of all types of structural elements, particularly structures located in marine environments. To eliminate concrete deterioration due to sulfate attack, water-proofing coatings such as coat tar, chlorinated rubber, and epoxy have been applied specifically to piers and footing abutments [16]. Waterproofing with reinforced concrete structures minimizes the corrosion rate [4]. Thus, the main purpose of a water-proofing coating system is to prohibit any deleterious substances from penetrating the reinforced concrete structures, which causes corrosion deterioration.

Hydrophobic coating is a waterproofing coating on the external surface of concrete structures, which is used to combat the problem of corrosion deterioration and to extend the service life of concrete structures [3]. It helps form a passive layer that is used to resist the attack of chloride ions. It can prevent steel reinforcement corrosion and prolong the service life of structures [40]. Furthermore, it has the ability to make concrete less susceptible to water saturation [9]. In addition, hydrophobic coatings have been found to be simple in application and have good adhesion to any type of base material [32].

Hydrophobic coatings with polyurethane protect structural concrete materials from abrasion, weathering, and corrosion, which would degrade the material properties [32]. Polyurethane comes from polymers that were created in the nineteen-thirties [18]. It was originally defined as a product of polyisocyanates and polyols [9]. It is considered to be one of the best multipurpose polymers in the industry, which can protect the material surface. It can be opaque or transparent and can be glossy or muted [29].

Polyurethane coatings are used to seal marine structures from corrosion, coastal elements, and harsh weather [32]. According to Di Mundo et al., polyurethane is an effective barrier against water ingress [14]. It is a durable covering material that can withstand high pressures and harsh environments; however, direct exposure to sunlight over a long period of time can weaken its strength [11]. Thus, the exposure of polyurethane coats to ultraviolet light must be limited, as it may degrade the effectiveness of the applied coat [16]. However, polyurethane coatings are not flammable and can be used when combustion occurs in the same environment [18].

Polyurethane coats have remarkable applications in a wide variety of materials [9]. It is applied to all categories of boats and ships, or various sizes and uses [40]. Polyurethane-based polymers provide an effective barrier to metals [16]. In addition, the permeability of concrete specimens with polyurethane coatings is reportedly lower than that of uncoated control concrete [18]. Furthermore, it considerably reduces the diffusion of carbon dioxide into the concrete matrix [40].

Polyurethane is hard and has a thicker film, which provides exceptional wear resistance. The application is allowed to stretch without destroying the coats, which are considered soft and ductile. The application is simple and does not require additional procedures [18]. They can be sprayed or rolled onto concrete materials [29].

This study evaluated the effectiveness of concrete coated with concrete surface coatings, which are polyurethane coatings, to preserve concrete durability. Several tests were conducted to measure the mechanical properties of the specimens. The galvanostatic method for accelerating corrosion was employed in a simulated environment. Data were gathered during and after corrosion acceleration 
procedures.

\section{Materials and Methods}

\subsection{Research Flow Chart}

The following were the procedures covered during the study: characterization of the materials and variables, specimen preparation, coating preparation, testing of specimens, corrosion acceleration method, and measurement of corrosion indices and research variables. The research methodology is illustrated in Figure 1.

\subsection{Specimen Preparation}

Experiments were performed at the Engineering Material's laboratory of Palawan State University Campus, Puerto Princesa City, Palawan, Philippines. The materials used for the research included cement, fine aggregates, and a polyurethane primer coat. The concrete was designed according to the ACI-211 mix proportion for the Class AA mixture, as shown in Table 1. The water-to-cement ratio is 0.45 . The water-to-cement ratio of 0.45 was based on ACI-211 for concrete structures exposed to an aggressive marine environment [1]. Table 2 lists the concrete mixtures of materials used in the design.

Table 1. Materials proportion of designed concrete mix

\begin{tabular}{c|c|c|c}
\hline Cement & Sand & Gravel & Water / Cement ratio \\
\hline 1 & 1.63 & 2.12 & 0.45 \\
\hline
\end{tabular}

Table 2. Materials of Concrete Mixtures

\begin{tabular}{c|c}
\hline Material & $\mathrm{Kg} \mathrm{per}^{3}$ of concrete \\
\hline Cement & 463 \\
Fine Aggregates & 754 \\
Coarse Aggregate & 982 \\
Water & 185 \\
\hline
\end{tabular}

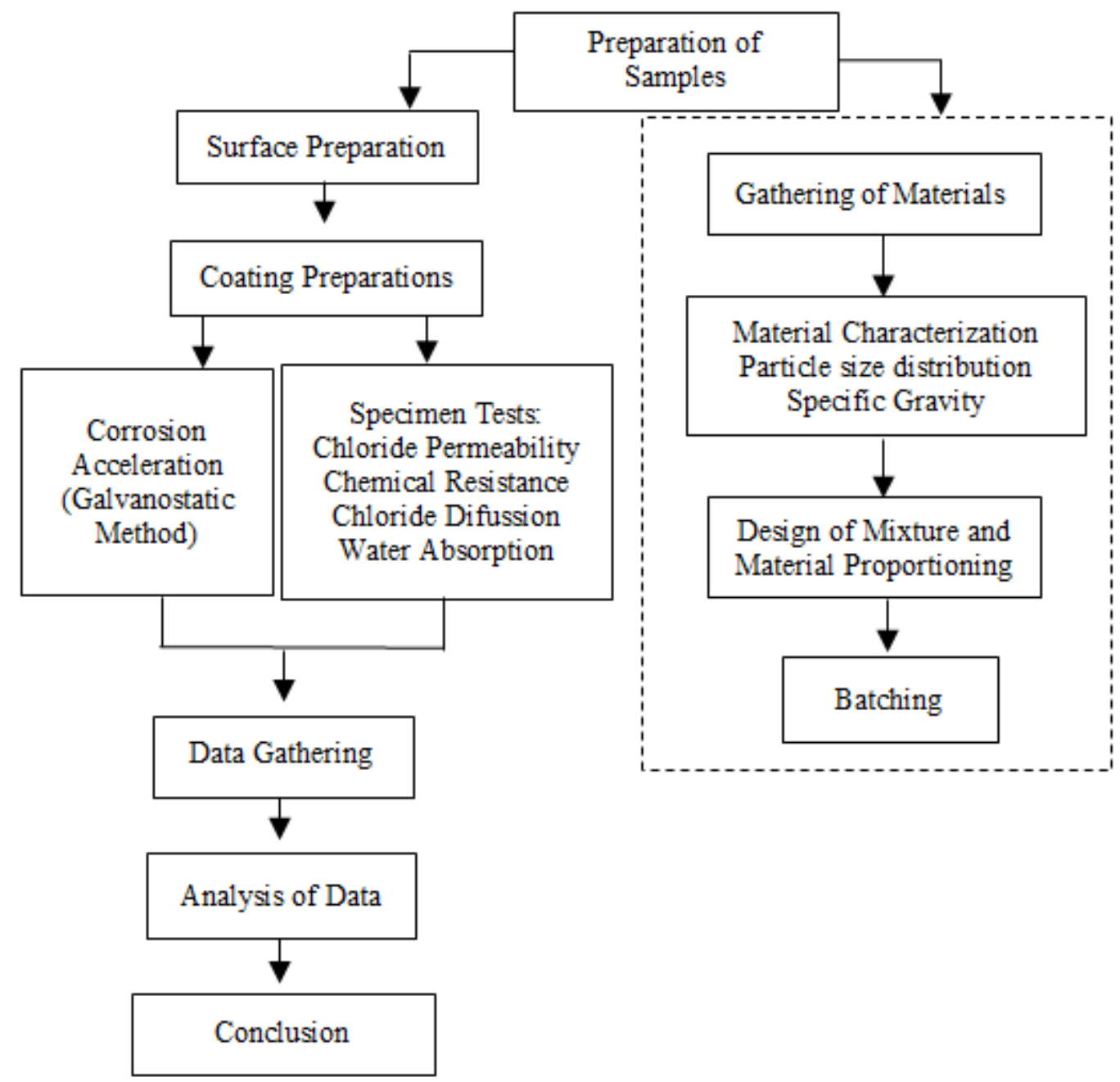

Figure 1. Research flow chart 
The following description of the specimens was prepared for conducting the following series of tests to evaluate the mechanical properties of the specimen with polyurethane coatings on its surface.

\subsubsection{Chloride Permeability}

Ten (10) pcs - $75 \mathrm{~mm}$ diameter and $50 \mathrm{~mm}$ thick concrete discs were cast to evaluate chloride permeability.

\subsubsection{Chemical Resistance}

Ten (10) pcs $-25 \mathrm{~mm}$ x $25 \mathrm{~mm}$ x $25 \mathrm{~mm}$ cube specimens were cast to evaluate the chemical resistance of the polyurethane coats.

In addition, six (6) pcs $-150 \mathrm{~mm}$ in diameter and $300 \mathrm{~mm}$ in height were cast to evaluate acid resistance. Three (3) pcs were uncoated, while the other three (3) pcs were coated

\subsubsection{Chloride Diffusion}

Ten (10) pcs - 100mm diameter and $50 \mathrm{~mm}$ thick concrete discs were cast to evaluate chloride diffusion.

\subsubsection{Water Absorption}

Ten (10) pcs - 50mm-diameter and $75 \mathrm{~mm}$ mortar specimens in cylindrical shapes were cast in evaluating the water absorption of the coated and uncoated specimens.

\subsubsection{Waterproofing materials}

Polyurethane coats consist of interlaminar primers and epoxy-based paints. It is a polyurethane primer containing polymers and polyester resins.

A summary of the number of specimens tested and their descriptions are presented in Table 3 .

Table 3. Descriptive Summary of Specimens

\begin{tabular}{|c|c|c|c|}
\hline Test & $\begin{array}{c}\text { Test } \\
\text { Method }\end{array}$ & $\begin{array}{c}\text { No. of } \\
\text { Specimens }\end{array}$ & Description \\
\hline $\begin{array}{c}\text { Chloride } \\
\text { Permeability }\end{array}$ & $\begin{array}{l}\text { ASTM } \\
\text { C } 1202\end{array}$ & $10 \mathrm{pcs}$ & $\begin{array}{c}75 \mathrm{~mm} \text { diameter and } \\
50 \mathrm{~mm} \text { thick concrete } \\
\text { discs }\end{array}$ \\
\hline $\begin{array}{l}\text { Chemical } \\
\text { Resistance }\end{array}$ & & $\begin{array}{l}10 \mathrm{pcs} \\
6 \mathrm{pcs}\end{array}$ & $\begin{array}{c}25 \mathrm{~mm} \times 25 \mathrm{~mm} \times \\
25 \mathrm{~mm} \text { cube } \\
150 \mathrm{~mm} \text { diameter and } \\
300 \mathrm{~mm} \text { height }\end{array}$ \\
\hline $\begin{array}{l}\text { Chloride } \\
\text { Diffusion }\end{array}$ & & $10 \mathrm{pcs}$ & $\begin{array}{l}\text { 100mm-diameter and } \\
50 \mathrm{~mm} \text { thick concrete } \\
\text { discs }\end{array}$ \\
\hline $\begin{array}{c}\text { Water } \\
\text { Absorption }\end{array}$ & $\begin{array}{c}\text { ASTM } \\
\text { C } 642\end{array}$ & 10 pcs & $\begin{array}{c}\text { 50mm-diameter and } \\
75 \mathrm{~mm} \text { high cylindrical } \\
\text { mortar specimens }\end{array}$ \\
\hline $\begin{array}{c}\text { Accelerated } \\
\text { corrosion }\end{array}$ & & $12 \mathrm{pcs}$ & $\begin{array}{l}\text { Cylindrical specimen of } \\
\text { 150mm-diameter and } \\
\text { 300mm-height }\end{array}$ \\
\hline
\end{tabular}

\subsubsection{Corrosion Acceleration}

Cylindrical specimens with a diameter of $150 \mathrm{~mm}$ and a height of $300 \mathrm{~mm}$ were cast using the specimen description, as shown in Table 4. These specimens were singly reinforced longitudinally with a $500 \mathrm{~mm}$ long deformed steel rebar. A typical diameter $(16 \mathrm{~mm})$ of the deformed steel reinforcement rebar was used, and a clear distance of $50 \mathrm{~mm}$ was provided at the bottom of the specimen. Twelve cube specimens were prepared and used in this study.

Table 4. Description of Specimen

\begin{tabular}{c|c}
\hline Specimen ID & Rebar diameter (mm) \\
\hline I-1 & \\
I-2 & \\
I-3 & \\
I-4 & \\
I-5 & \\
I-6 & \\
I-7 & \\
I-8 & \\
I-9 & \\
I-10 & \\
I-11 & \\
I-12 & \\
\hline
\end{tabular}

The concrete constituents were mixed in concrete mixer equipment with a $3.50 \mathrm{HP}$ capacity for approximately 5 min to attain uniform consistency. The molds were filled in two layers with concrete mortar and vibrated for a firm association of the materials. After casting, all specimens except those for the corrosion acceleration test were covered with wet clean fiber cloths and plastic sheets. They were subjected to curing for approximately two (2) weeks. The fiber cloths were kept wet throughout the duration of specimen curing period. After two (2) weeks of curing, they were placed in an oven at $70^{\circ} \mathrm{c}$ for $24 \mathrm{~h}$. They were air-dried at room temperature for $24 \mathrm{~h}$ before being subjected to polyurethane coatings.

In each test, two groups of concrete specimens were cast for the uncoated specimens and specimens coated with polyurethane coatings. Based on ASTM C192, all cast specimens were cured using cyclic wetting and drying procedures under laboratory conditions [16]:

- During wetting and drying, the specimen was submerged in water for $24 \mathrm{~h}$, after which it was dried in the laboratory. The wetting and drying processes were continued for three months.

- During heating and cooling curing, the specimen was heated for $8 \mathrm{~h}$ at $70^{\circ} \mathrm{C}$, and then cooled for $16 \mathrm{~h}$ at the temperature of the laboratory room. The heating duration was $15 \mathrm{~min}$, and the cooling time was 90 min. Heating and cooling cycles were continued for three months.

Fig. 2 shows the details of the specimen, and Fig. 3 shows a schematic of the prism specimen for all specimens subjected to corrosion acceleration tests. 


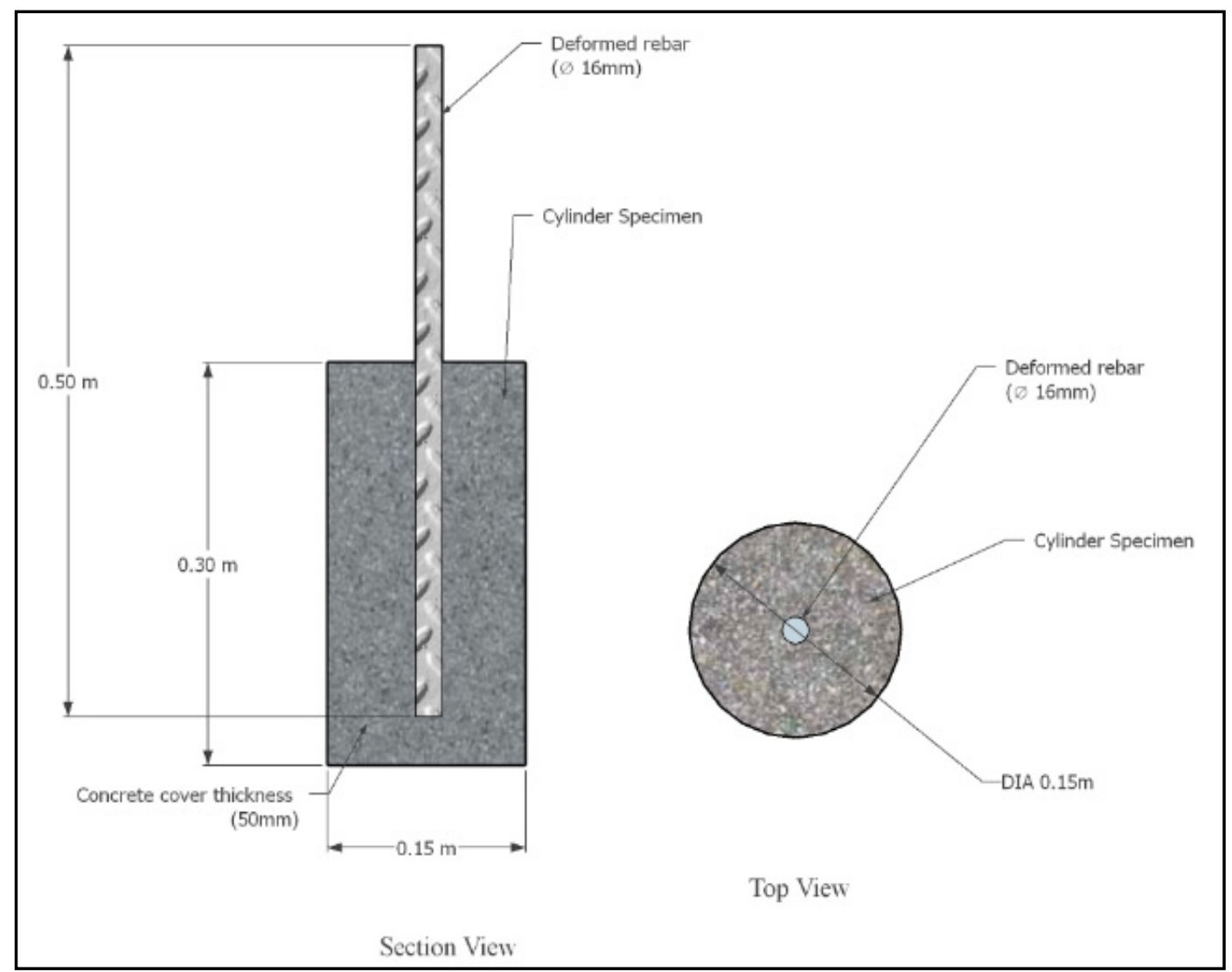

Figure 2. Detail of Specimen

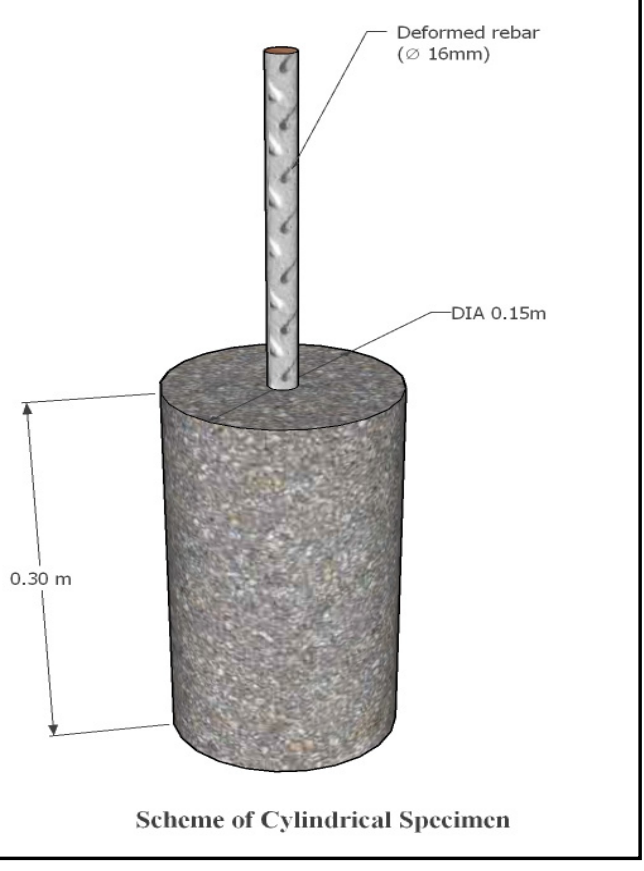

Figure 3. Scheme of Cylindrical Specimen

\subsection{Surface Preparation}

The mortar specimens were cleaned before the application of polyurethane coats. Each surface and corner of the specimen must be carefully monitored to avoid disintegration of its parts or surfaces.

\subsection{Coating Application}

After 28-days of curing, a hydrophobic coating was applied to the cast specimens. A polyurethane coating was applied with the aid of a 2-inch-wide paint brush on the surface of the concrete specimens. A three (3)-coat application was considered for concealing the rough surface of the concrete specimen. Polyurethane covers 12.00 sq.m per liter.

\subsection{Test of Specimen}

\subsubsection{Chloride Permeability}

A diameter of $75 \mathrm{~mm}$ ( 3 inches) and a height of $50 \mathrm{~mm}$ were obtained from a cylindrical concrete sample. The surfaces of the specimens were coated with polyurethane coats. After the coats were dried, they were placed in a vacuum chamber for $3 \mathrm{~h}$. In the test device, the left-hand side (-) of the test cell was filled with a $3 \% \mathrm{NaCl}$ solution, and the right-hand side $(+)$ of the test cell was filled with $0.30 \mathrm{~N} \mathrm{NaOH}$ solution. A 60 -volt potential was applied for a period of $6 \mathrm{~h}$. Readings were taken every $30 \mathrm{~min}$. The number of coulombs passing through the specimen was calculated after $6 \mathrm{~h}$, after which the specimen samples 
were removed.

\subsubsection{Chemical Resistance}

a) For specimen of $25 \mathrm{~mm} \times 25 \mathrm{~mm} \times 25 \mathrm{~mm}$ cubes:

Polyurethane coats were applied to all faces of the cement mortar specimens. After coating, the samples were immersed in a $2.50 \%$ sulfuric acid solution.

At regular intervals, the specimens were visually monitored for any signs of coating deterioration. Almusallam et al. provided a descriptive rating of the extent of coating deterioration of specimens subjected to several external concrete surface coating systems. A rating with descriptive numbers is shown in Table 5, which summarizes the rating system.

Table 5. Descriptive Rating [2]

\begin{tabular}{|c|c|}
\hline Rating & Description \\
\hline 1 & Coating intact \\
\hline 2 & Corners Damaged \\
\hline 3 & Corners and edges deteriorated \\
\hline 4 & Corners, edges and some surface damage \\
\hline 5 & Coating delamination and/or Dissolution \\
\hline
\end{tabular}

b) For specimen of $150 \mathrm{~mm}$-diameter and $300 \mathrm{~mm}$ height cylinder:

After 28 days of water curing, the specimens were immersed in a solution of $5 \%$ sulfuric acid $\mathrm{H}_{2} \mathrm{SO}_{4}$. The specimens were again immersed in potable water for a period of 10-days. After a 10-days period, cylindrical specimens were weighed to determine the weight loss due to acid attack. The compressive strength of the specimens was determined before and after immersion to determine the strength loss due to acid attack. These descriptions are presented in Table 6.

Table 6. Description of Specimen

*(Acid Resistance Test)

\begin{tabular}{c|c|c|c}
\hline \multirow{2}{*}{$\begin{array}{c}\text { Designation } \\
\text { of Samples }\end{array}$} & Description & $\begin{array}{c}\text { Dimension } \\
(\mathrm{mm})\end{array}$ & QTY \\
\hline $\mathrm{A}$ & $\begin{array}{c}\text { Without Polyurethane } \\
\text { Coating }\end{array}$ & 3 \\
\hline $\mathrm{B}$ & $\begin{array}{c}\text { With Polyurethane for } \\
\text { Hydrophobic Coatings }\end{array}$ & $\begin{array}{c}300 \text { height } \\
\end{array}$ & 3 \\
\hline
\end{tabular}

\subsubsection{Chloride Diffusion}

\subsubsection{Estimation of chloride diffusion coefficients}

A specimen with a diameter of $100 \mathrm{~mm}$ and height of $200 \mathrm{~mm}$ was sawed into four (4) parts. After drying the concrete slices, polyurethane coatings were applied to one of the faces of the specimens. After seven (7) days, the specimens were broken, and the depth of chloride penetration was determined using Equation 1.

The chloride diffusion coefficient was determined using the procedure described by Luping and Nilsson. The method involved breaking the concrete specimen and measuring the depth of color that changed on the surface of the concrete with $0.10 \mathrm{M} \mathrm{AgNO} 3$ aqueous solution.

$$
D=\frac{R T}{z F E} \frac{x_{d}-a x_{d}^{b}}{t}
$$

Where:

$$
\begin{aligned}
& \mathrm{D}=\text { Diffusion coefficient }\left(\mathrm{cm}^{2} / \mathrm{s}\right) \\
& \mathrm{R}=\text { gas constant }(\mathrm{J} / \mathrm{molK}) \\
& \mathrm{T}=\text { temperature }(\mathrm{K})(298 \mathrm{~K}) \\
& \mathrm{Z}=\text { valency of the ion }(\text { for chloride ion } \mathrm{z}=-1) \\
& \mathrm{F}=\text { Faraday constant }(\mathrm{J} / \mathrm{V} . \mathrm{mol}) \\
& \mathrm{E}=\text { Field density }(\mathrm{V} / \mathrm{m})(-600 \mathrm{~V} / \mathrm{m}) \\
& \mathrm{X}_{\mathrm{d}}=\text { penetration } \operatorname{depth}(\mathrm{m}) \\
& \mathrm{t}=\text { test time }(\mathrm{s}) \\
& \mathrm{a}=\text { test constant }(1.061) \\
& \mathrm{b}=\text { test constant }(0.589)
\end{aligned}
$$

\subsubsection{Water Absorption}

The entire surfaces of cylindrical specimens of $50 \mathrm{~mm}$ diameter and $75 \mathrm{~mm}$ height were painted using polyurethane coats. After the coatings had dried, they were weighed before being placed in a water tank. After $7 \mathrm{~h}$, the weight of the samples was recorded for up to $56 \mathrm{~h}$. ASTM C 642 was used for the evaluation of all the specimens subjected to the water absorption test.

\subsection{Accelerated Corrosion Program}

After 28 days curing period, sample specimens were partially immersed with $5 \% \mathrm{NaCl}$ solution as a simulated environment for a period of thirty (30) days. The galvanostatic method with the impressed current technique was used to accelerate the corrosion of the reinforcing steel with a constant current density of 50 Ampere $/ \mathrm{cm}^{2}$. Every ten (10) other days, the specimens were subjected to accelerations for $30 \mathrm{~min}$ for each specimen.

Figure 4 illustrates the scheme used to accelerate the corrosion of the specimens. The wires were connected to the positive and negative poles of the power supply. 


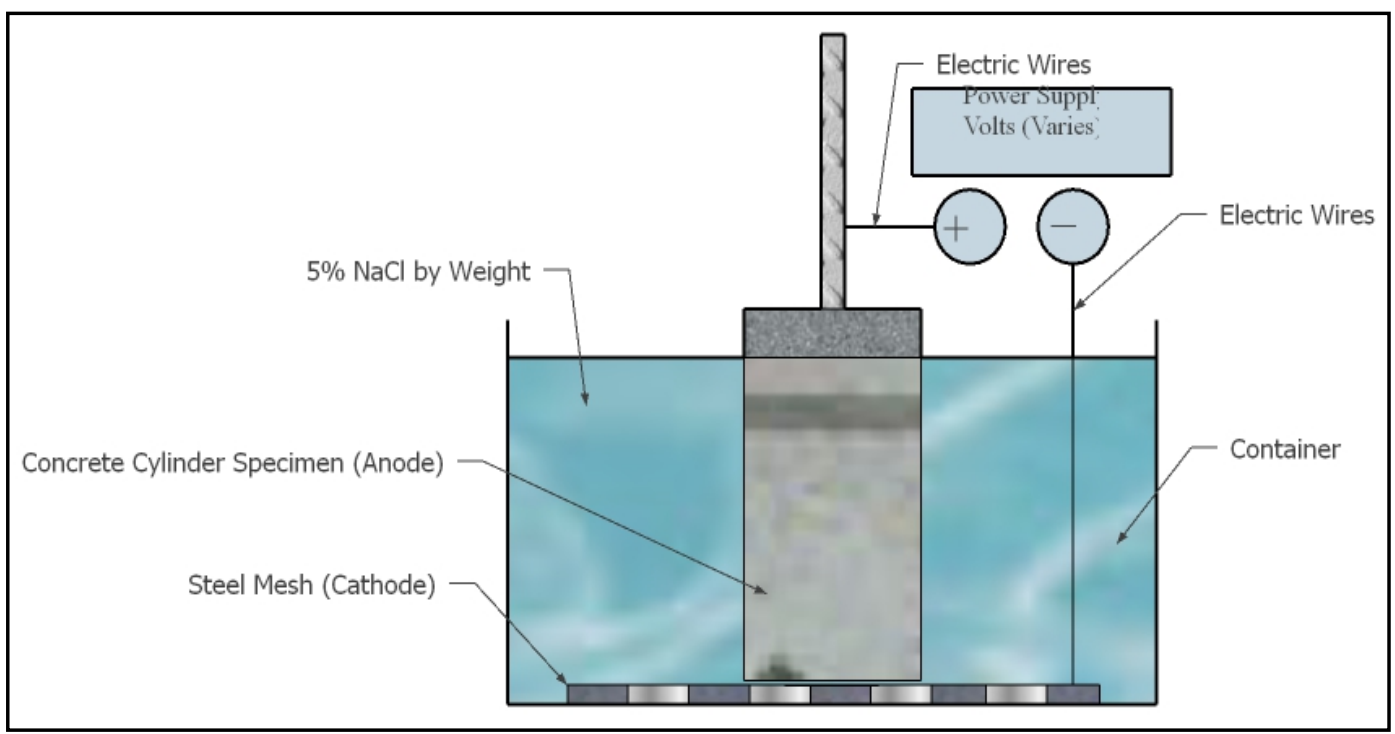

Figure 4. Test layout to accelerate corrosion

The purpose of this test was to evaluate the effectiveness of polyurethane against corrosion deterioration of structures exposed to severe marine environments.

\subsection{Measuring Parameters}

Crack evolution was measured using a crack ruler with the smallest reading of $0.001 \mathrm{~mm}$. Crack indices, including crack frequency, crack width, and crack depth, were recorded and tabulated.

\subsection{Area Calculations}

After the crack indices were recorded, the specimens were broken to pass the embedded steel reinforcement bars. The weight of each specimen before and after corrosion acceleration was recorded. The reduced diameter of the steel reinforcements was determined from the weight of each corroded bare steel rebar. The reduced diameter was estimated from the weight of the rebar, owing to irregular alterations in diameter.

$$
\text { Actual area }=\mathrm{W}_{1} /\left(\mathrm{L} \times \gamma_{\text {iron }}\right)
$$

Where:

$\mathrm{W}_{1}=$ weight of steel after rust removal $(\mathrm{g})$

$\mathrm{L}=$ length of steel reinforcement $(\mathrm{mm})$

$\gamma_{\text {iron }}=0.00785 \mathrm{~g} / \mathrm{mm}^{3}$

The actual weight of the accumulated corrosion products, that is, per unit surface area in accordance with ASTM G, was calculated as

$$
\mathrm{Mac}=\frac{\left(\mathrm{W}_{\mathrm{i}}-\mathrm{W}_{\mathrm{f}}\right)}{\pi \mathrm{DL}}
$$

Where:

$\mathrm{M}_{\mathrm{ac}}=$ weight of accumulated rust $\left(\mathrm{g} / \mathrm{cm}^{2}\right)$

$\mathrm{W}_{\mathrm{i}}=$ initial weight of the bar before corrosion $(\mathrm{g})$
$\mathrm{W}_{\mathrm{f}}=$ weight after corrosion $(\mathrm{g})$

$\mathrm{D}=$ steel reinforcement $(\mathrm{cm})$

$\mathrm{L}=$ length of steel reinforcement ( $\mathrm{mm})$

Rate of corrosion was determined using corrosion current density, $\mathrm{i}_{\text {corr }}$ :

$$
\mathrm{i}_{\text {corr }}=\frac{\mathrm{M}_{\mathrm{ac}} \mathrm{F}}{\mathrm{EWt}}
$$

Where:

$\mathrm{i}_{\text {corr }}=$ corrosion current density $\left(\mu \mathrm{Amp} / \mathrm{cm}^{2}\right)$

$\mathrm{M}_{\mathrm{ac}}=$ weight of accumulated rust $\left(\mathrm{g} / \mathrm{cm}^{2}\right)$

$\mathrm{F}=$ Faraday's constant (96487 Amp-sec)

$\mathrm{EW}=$ Equivalent weight of element (27.925 for steel)

$\mathrm{t}=$ Time of accelerating corrosion ( $\mathrm{sec}$ )

Corrosion rates were also determined in terms of Penetration rate, designated as CR:

$$
\mathrm{CR}=\mathrm{K}_{1}\left(\mathrm{i}_{\mathrm{cor}} / \rho\right) \mathrm{EW}
$$

Where:

$\mathrm{CR}=$ Penetration rate $(\mathrm{mm} /$ year $)$

$\mathrm{i}_{\text {corr }}=$ corrosion current density $\left(\mu \mathrm{Amp} / \mathrm{cm}^{2}\right)$

$\mathrm{K}_{1}=3.27 \times 10^{-3} \mathrm{~mm} \mathrm{~g} / \mu \mathrm{A} \mathrm{cm} . \mathrm{yr}$

$\rho=7.85 \mathrm{~g} / \mathrm{cm}^{3}$ for steel (density)

$\mathrm{EW}=$ equivalent weight of element (27.93 for steel)

Mass loss rate was also determined using the formula:

$$
\mathrm{MR}=\mathrm{K}_{2} \quad \mathrm{i}_{\text {corr }} \mathrm{EW} \mathrm{g} / \mathrm{m}^{2} \mathrm{~d}
$$

Where:

$\mathrm{MR}=$ Mass loss rate $\left(\mathrm{g} / \mathrm{m}^{2} \mathrm{~d}\right)$

$\mathrm{i}_{\text {corr }}=$ corrosion current density $\left(\mu \mathrm{Amp} / \mathrm{cm}^{2}\right)$

$\mathrm{K}_{2}=8.954 \times 10^{-3} \mathrm{~g} \cdot \mathrm{cm}^{2} / \mu \mathrm{A} \mathrm{m} \mathrm{d}^{2}$ 
$\mathrm{EW}=$ Equivalent weight of element (27.925 for steel)

From the penetration rate formula, designated as CR, real-time in a year (s) and days were calculated using Equation 7 [22]:

Accelerated real-time (years) $=$ loss in diameter $/ \mathrm{CR}$

Degree of corrosion, designated as $\mathrm{C}_{\mathrm{deg}}$ was calculated as:

$$
\mathrm{C}_{\text {deg }}=\left(\mathrm{W}_{\mathrm{i}}-\mathrm{W}_{\mathrm{f}}\right) / \mathrm{W}_{\mathrm{i}} \times 100
$$

Where:

$$
\begin{aligned}
& \mathrm{W}_{\mathrm{i}}=\text { is the weight of the bar before Corrosion }(\mathrm{g}) \\
& \mathrm{W}_{\mathrm{f}}=\text { is the weight of the bar after Corrosion }(\mathrm{g})
\end{aligned}
$$

\section{Results and Discussion}

The following were the results of the analysis from the experiments conducted.

\subsection{Chloride Permeability}

The rapid chloride permeability test measures the electric charges passing through the sliced concrete specimens $[2,6,13,15,17]$. Both sides of the specimen were in contact with a sodium hydroxide solution. The amount of electrical current passed through the 2 -inch-thick slice for a period of $6 \mathrm{~h}$ under $60 \mathrm{~V} \mathrm{DC}$ was recorded as the coulomb rating.

From the results of the experiments conducted, the measured electrical charges that pass through the coated specimens on average is 7.41 coulomb, while uncoated specimens have an average of 897.15 coulombs. Table 7 provides a classification based on ASTM C 1202 for the specimens subjected to chloride permeability tests. As shown in Table 7, the specimens with polyurethane coatings had negligible chloride permeability, whereas the uncoated base materials had low permeability.

The results were consistent with those of a similar study conducted by Almusallam et al., who found that compared with chlorinated rubber coatings that have 39-50 Coulombs of chloride permeability, polyurethane coatings have only 6-40 coulombs [2]. According to Al-Zahrani et al., the chloride ion permeability of a polyurethane-based coating system has a negligible chloride permeability throughout the exposure period, compared with cement-based coating and cement-based polymer-modified coating, which increases from negligible to low, based on the results of their study [4].

Table 7. Total Coating charge with ASTM C 1202 Classification

\begin{tabular}{c|c|c}
\hline Coating & $\begin{array}{c}\text { Charge passed } \\
\text { (Coulombs) }\end{array}$ & $\begin{array}{c}\text { ASTM C 1202 } \\
\text { Classification }\end{array}$ \\
\hline $\begin{array}{c}\text { Polyurethane coating } \\
\text { None }\end{array}$ & 7.41 & Negligible \\
897.15 & Low \\
\hline
\end{tabular}

Furthermore, Suprenant B. provides five (5) categories of coulombs that describe the chloride permeability and a typical description of the water-cement ratio of a conventional Portland cement, as shown in Table 8.

The range of values was established in the laboratory using the method described in ASTM C 1202.

Table 8. Chloride Permeability [36]

*Based on Charge Passed

\begin{tabular}{c|c|l}
\hline $\begin{array}{c}\text { Charge Passed } \\
\text { (coulombs })\end{array}$ & $\begin{array}{c}\text { Chloride } \\
\text { Permeability }\end{array}$ & \multicolumn{1}{|c}{ Typical of } \\
\hline$>4000$ & High & $\begin{array}{l}\text { High water-cement ratio } \\
(>0.60), \text { conventional PCC } \\
\text { Moderate water-cement ratio } \\
(0.40 \text { to } 0.50), \text { conventional } \\
\text { PCC }\end{array}$ \\
$1000-4000$ & Low & $\begin{array}{l}\text { Low water-cement ratio }(<0.40), \\
\text { conventional PCC } \\
\text { Latex-modified concrete, or } \\
\text { internally-sealed concrete } \\
\text { Polymer impregnated concrete, } \\
\text { polymer concrete }\end{array}$ \\
\hline
\end{tabular}

According to Suprerant, concrete with high permeability has a higher Coulomb, whereas those with lower coulombs have a lower permeability [36]. Based on the table provided by Suprenant B., the chloride permeability of coated polyurethane coatings is negligible because it has 7.41 coulombs. The uncoated base specimen which has 897.15 coulombs is considered to have very low chloride permeability.

According to the results, the chloride permeability of the concrete specimens coated with polyurethane was almost one-eighth that of the uncoated concrete. Confirming the work of Al-Zahrani et al., concrete specimens coated with polyurethane coatings showed negligible chloride permeability during the exposure period [4]. Thus, polyurethane coats prohibit the ingress of aggressive elements into a concrete mortar, and a tough film from the coats makes concrete with low porosity [11].

\subsection{Chemical Resistance}

Acid resistance is a desirable property for structural materials exposed to an aggressive marine environment, such as seawater. An acid attack causes the concrete to lose its strength and quickly deteriorates.

The application of polyurethane coatings on the concrete mortar specimens was evaluated by visual inspection while it was immersed in a solution containing $2.50 \%$ sulfuric acid. Cast specimens were evaluated using a descriptive deteriorated rating with a numeric indicator provided by Almusallam et al. This information is summarized in Table 9.

As shown in Table 9, the specimen with polyurethane coatings showed no deterioration. However, during 30 days curing period, a slight deterioration of the specimens was observed. Specimens without coatings show complete deterioration even at the early stage of their curing, that is, in a 3-days period. According to Almusallam et al., mortar specimens coated with polyurethanes and epoxy coatings 
were relatively intact even after a 60 days period, whereas those with polymer emulsion deteriorated faster in 30 days period [2].

Table 9. Descriptive Rating of Deterioration [2]

\begin{tabular}{c|c|c|c|c|c}
\hline \multirow{2}{*}{ Coating } & \multicolumn{5}{|c}{$\begin{array}{c}\text { Deterioration rating, after (days) } \\
\text { *Criteria: 5 - indicate complete deterioration; } \\
1-\text { indicate no deterioration }\end{array}$} \\
\cline { 2 - 6 } & 3 & 7 & 21 & 30 & 60 \\
\hline $\begin{array}{c}\text { Polyurethane } \\
\text { coating } \\
\text { None }\end{array}$ & 1 & 1 & 1 & 2 & 2 \\
\end{tabular}

It was also verified from Fig. 5 that the specimen without coatings had a larger weight reduction, while the specimen with polyurethane coatings had a lower percent weight reduction, considering acid penetration. Table 10 shows the tabulation of the weight reductions of each specimen using the acid resistance test.

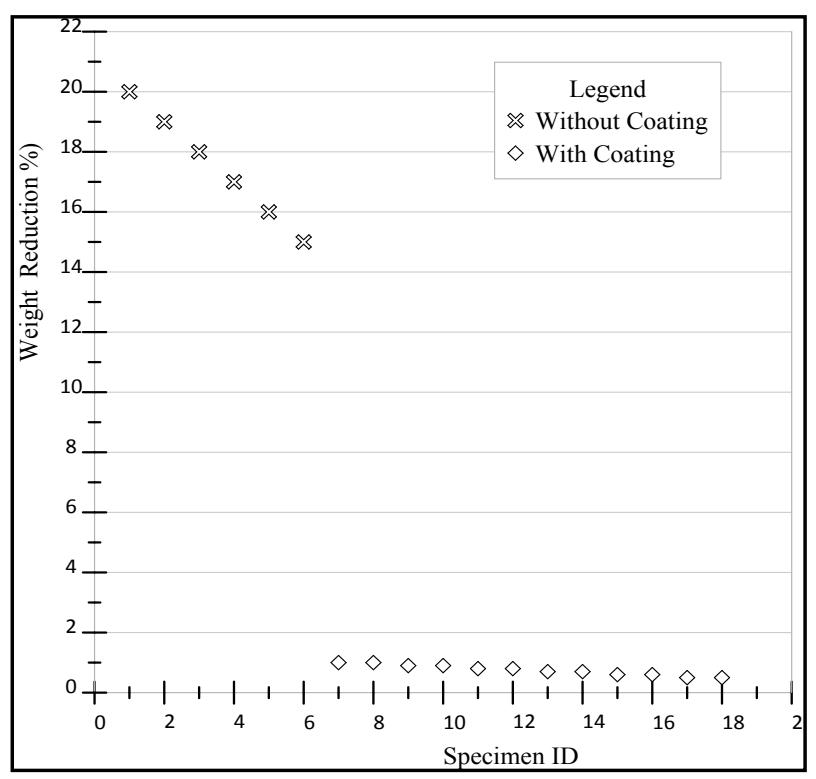

Figure 5. Weight Reduction in Acid Resistant Test

Table 10. Weight loss of Specimen in Acid Resistance Test

\begin{tabular}{c|c|c|c}
\hline $\begin{array}{c}\text { Designation of } \\
\text { Samples }\end{array}$ & $\begin{array}{c}\text { Weight } \\
\text { in Before } \\
\text { Test }\end{array}$ & $\begin{array}{c}\text { Weight } \\
\text { in After } \\
\text { Test }\end{array}$ & $\begin{array}{c}\text { Weight } \\
\text { Reduction (\%) }\end{array}$ \\
\hline ART-A & 2.700 & 2.690 & 0.70 \\
\hline ART-B & 2.675 & 2.630 & 0.50 \\
\hline ART-C & 2.645 & 2.637 & 0.80 \\
\hline ART-D & 2.750 & 2.733 & 1.70 \\
\hline
\end{tabular}

\subsection{Chloride Diffusion}

\subsubsection{Chloride Diffusion Coefficient}

The value of the chloride diffusion coefficients was solved using the Ficks second law of diffusion and by the method used by Luping and Nilsson [38]. The concrete mortar specimens were then saturated. The data are summarized in Table 11.
Table 11. Chloride diffusion coefficients

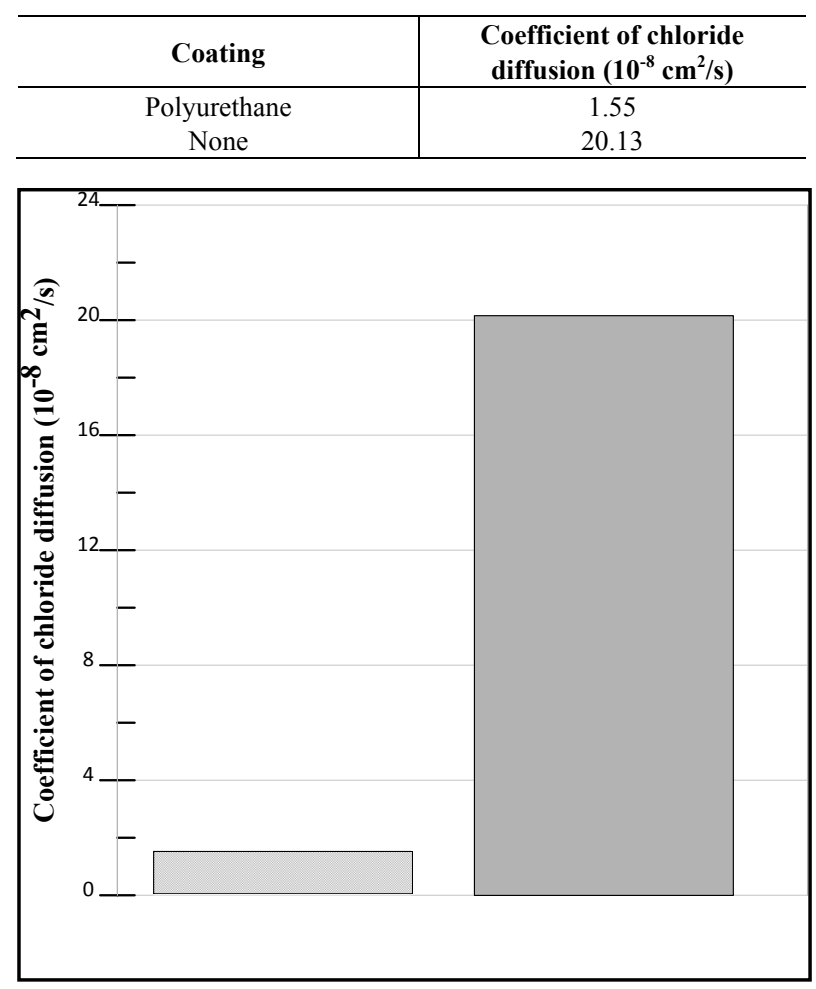

Figure 6. Chloride Diffusion Coefficients

Fig 6 shows the coefficient of chloride diffusion for each specimen. The uncoated concrete mortar specimen had a higher chloride diffusion coefficient than the coated specimen of polyurethane coats. The value in the uncoated concrete specimen was $20.13^{\times} 10^{-8} \mathrm{~cm}^{2} / \mathrm{s}$. The specimen coated with polyurethane coatings had the lowest chloride diffusion coefficients with a value of $1.55^{x} 10^{-8} \mathrm{~cm}^{2} / \mathrm{s}$.

The effectiveness of polyurethane coatings in resisting the penetration of chloride ions is eight times more effective than that of uncoated concrete mortar specimens. Several authors have reported the effective performance of polyurethane coatings in reducing chloride diffusion in concrete. According to Almusallam et al., specimens with polyurethane coatings have the lowest chloride diffusion, with values of $0.70 \times 10^{-8}$ to $1.80 \times 10^{-8} \mathrm{~cm}^{2} / \mathrm{s}$ [2]. In the work of Medeiros and Helene, the efficacy of hydrophobic agents, acrylic coating, and polyurethane coatings in inhibiting chloride penetration in concrete was investigated. The results show that the chloride diffusion coefficient was reduced by approximately $86 \%$ when polyurethane coating was used as compared to the base concrete. Thus, the reduction in the chloride diffusion coefficient helps to lengthen the serviceability of structures exposed to an aggressive marine environment [25].

\subsubsection{Required minimum concrete cover thickness}

Calculating the required minimum concrete cover thickness further emphasizes the effectiveness of polyurethane coatings. The model proposed by Poulsen et al., using Equation (9), was used to estimate the minimum 
concrete cover thickness required for reinforced concrete structures. The chloride concentration was assumed to be $<0.06 \%$ by weight of concrete, with a w/c ratio of 0.45 , and a service life of 50 years [24].

$$
c_{\min }=\sqrt{4 t_{L T} D_{a}} \times \operatorname{inv} \psi_{p}\left\{\frac{C_{c r}-C_{i}}{S\left(t_{L T} D_{a}\right)^{p}}\right\}
$$

Where:

$\mathrm{C}_{\min }=$ minimum concrete cover required (mm);

$\mathrm{t}_{\mathrm{LT}}=$ expected service lifetime (years $\left.=50\right)$;

$\mathrm{D}_{\mathrm{a}}=$ assumed diffusion coefficient (From Table 10);

$\psi_{p}=$ a function tabled by Mejlbro et al. [2].

$\mathrm{C}_{\mathrm{cr}}=$ critical chloride concentration $(\%)(<0.06 \%)$;

$\mathrm{C}_{\mathrm{i}}=$ initial percentage of chloride concentration; and

S \& $p=$ Swamy constant values

Based on the results of the experiment, the minimum concrete cover thickness required to prohibit the ingress of chloride ions within a 50 years period is summarized in Table 11. It requires $125 \mathrm{~mm}$ of concrete cover to reach a serviceability life of 50 years for specimens without coating. However, for the specimens with polyurethane coatings, it only requires a $23 \mathrm{~mm}$ thick concrete cover for the specimen to attain a service life of 50 years.

Table 11. Required Minimum Concrete Cover

\begin{tabular}{c|c}
\hline Coating & Cover $(\mathbf{m m})$ \\
\hline Polyurethane coating, & 22.13 \\
None & 123.14 \\
\hline
\end{tabular}

\subsubsection{Time of Corrosion Initiation}

The time for the initiation of corrosion in concrete structures was calculated using Equation 10. The chloride concentration proposed by Swamy et al., which is equal to $0.36 \%$ was used [37]. A summary of the corrosion initiation times for the coated and uncoated concrete specimens is presented in Table 12.

$$
\frac{C_{x}}{C_{S}}=1-\operatorname{erf}\left\{\frac{x}{2 \sqrt{D_{e} t}}\right\}
$$

Where:

$\mathrm{C}_{\mathrm{x}}=$ chloride concentration at depth $\mathrm{x}(\%)$;

$\mathrm{C}_{\mathrm{s}}=$ chloride concentration (\%);

$\mathrm{x}=$ depth from concrete surface $(\mathrm{mm})$;

$\mathrm{t}=$ time (s); and

$\mathrm{D}_{\mathrm{e}}=$ effective chloride diffusion coefficient $\left(\mathrm{cm}^{2} / \mathrm{s}\right)$

Table 12. Time to initiate corrosions

*(50mm concrete cover $)$

\begin{tabular}{c|c}
\hline Coating & $\begin{array}{c}\text { Time to initiation of } \\
\text { corrosion (years) }\end{array}$ \\
\hline Polyurethane coating & 13.40 \\
None & 1.16 \\
\hline
\end{tabular}

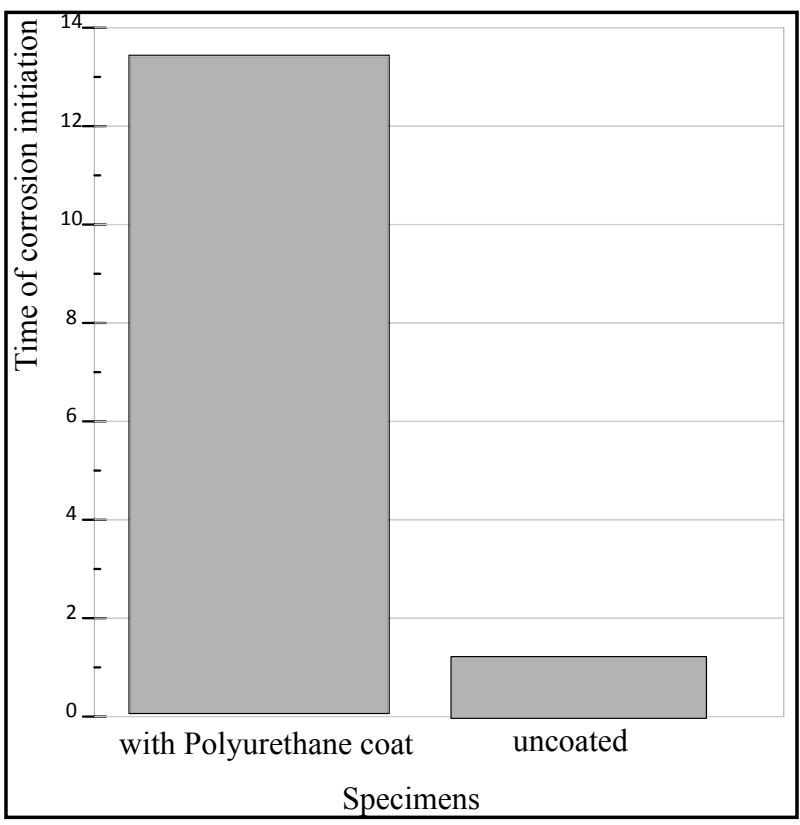

Figure 7. Time to initiate corrosion

Fig 7 shows the initiation time for corrosion of the steel reinforcement. It takes a long time, approximately 13 years before steel reinforcement will corrode with concrete specimens coated with polyurethane coatings. The steel reinforcement of specimens without polyurethane coatings corroded immediately after one year. It was confirmed with Al-Zahrani et al., using the accelerated corrosion test, results clearly showed that the specimens coated with the polyurethane-based coating system had superior performance against corrosion [4].

\subsection{Water Absorption}

The average weight of the specimens due to water absorption of the concrete after a $56 \mathrm{~h}$ period is tabulated in Table 13.

Table 13. Weight gained

\begin{tabular}{c|c}
\hline Coatings & Weight gain (\%) \\
\hline Polyurethane coating & 1.13 \\
None & 5.20 \\
\hline
\end{tabular}

As shown in Table 13, the uncoated concrete mortar specimens absorbed water by approximately $5 \%$ by weight, and the coated specimen absorbed $1 \%$.

From the work of Almusallam et al., acrylic coated specimens have water absorption of $0.23-1.46 \%$, chlorinated rubber coated specimens have water absorption of $0.76-1.04 \%$, specimen with epoxy coated absorbed water in the range of $0.27-1.30 \%$, and specimen with polyurethane coatings was about $0.21-1.83 \%$. Thus, for cement mortar specimens coated with epoxy and polyurethane coatings, the minimum weight gain was noted [2]. In addition, according to Al-Zahrani et al., the water absorption capacity of a polyurethane-based coating 
system decreased fourfold compared to that of the uncoated specimens and specimens coated with epoxy-based and cement-based coating systems [4]. In the work of Medeiros and Helene, the efficacy of hydrophobic agents, acrylic coating, and polyurethane coatings in inhibiting chloride penetration in concrete was investigated. The results show that polyurethane coating, compared to other products such as epoxy-based coating, was more effective in prohibiting the ingress of water to the surface of the concrete. Therefore, surface treatments reduced capillary water absorption from $73 \%$ to $98 \%$ compared to that of uncoated base materials. It should be considered that water that penetrates the concrete surface can be a vehicle for chemicals such as chloride ions [27].

Fig 8 shows the variations in weight gained by the coated and uncoated specimens with the water absorption test.

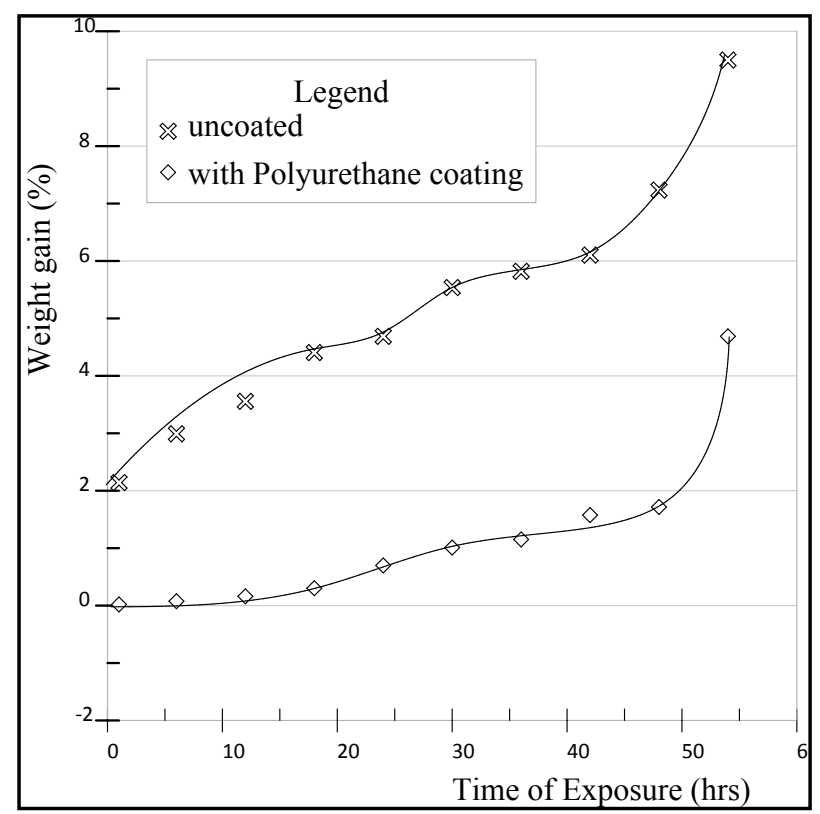

Figure 8. Variation of the weight gained due to water absorption

\subsection{Crack Indices}

\subsubsection{Crack Frequency}

The crack frequency is the number of cracks that appear on the surface of a specimen [7]. It is one of the fundamental factors that influence the amount of corrosion $[2,8]$. The multiple cracks generated indicate that more pathways for the deteriorating agents can penetrate the concrete surface [8]. These pathways allow the entry of water, oxygen, and chlorides, which helps to decompose the steel rebars into their original state, which is rust.

Concrete typically protects embedded reinforcement against corrosion [38]. The high $\mathrm{pH}$ value of concrete acts as a barrier to the ingress of aggressive elements such as chloride in a marine environment [19]. Initially, concrete has high alkalinity, which protects the steel against corrosion [34]. In the intrusion of deteriorating chemicals such as chloride, corrosion is initiated in the form of rust products, causing expansion of the concrete cover and leading to the formation of cracks on the concrete surface or cover.

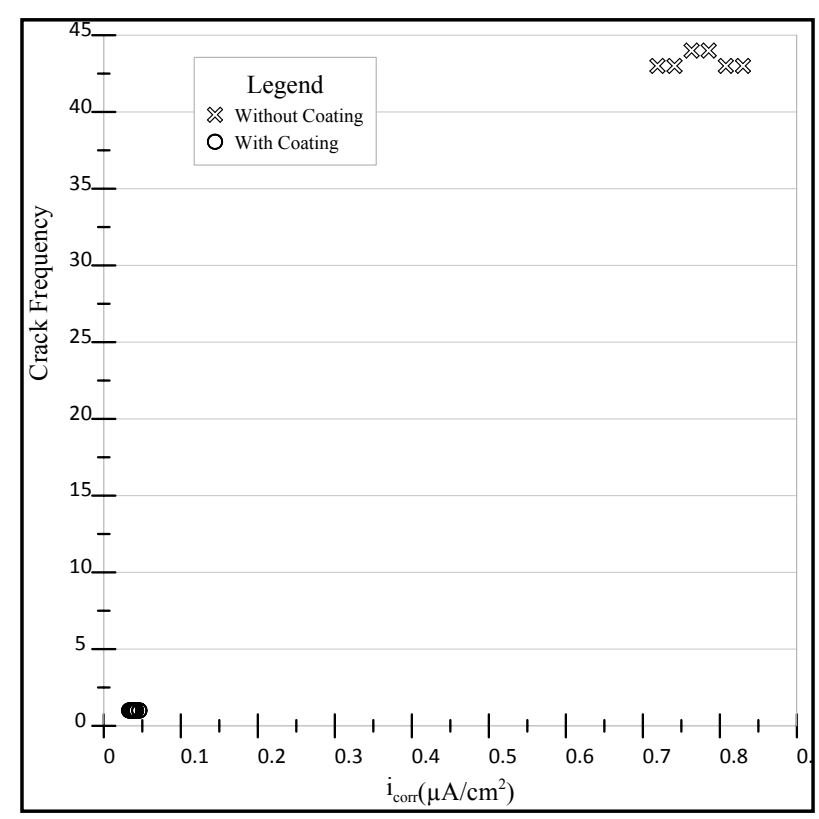

Figure 9. Correlation of Crack Frequency to Corrosion Rates

In general, specimens with higher crack frequencies have higher rates of corrosion, $I_{\text {corr }}\left(\mu \mathrm{A} / \mathrm{cm}^{2}\right)$, whereas specimens with lower crack frequencies have lower corrosion rates. The corrosion rates of samples with more cracks were higher than those of the specimens with fewer cracks [22]. Higher corrosion rates of steel reinforcement cause the concrete surface of the specimen to generate more cracks, which in turn leads to a high risk of deterioration.

From the experiments, 16mm-diameter deformed bars were used as reinforcements. Corrosion ranged from 0.33 to $0.83 \mu \mathrm{A} / \mathrm{cm}^{2}$. A group of specimens with polyurethane coatings exhibited lower corrosion rates. Compared with the control specimens, the corrosion rates were reduced by almost 96\%. Furthermore, as shown in Fig. 9, the crack frequency of the specimen with hydrophobic coatings reduced significantly to one or three cracks on all of its surfaces. The polyurethane coatings concealed the pore surfaces of the concrete specimens. This helps the concrete to have impermeable surfaces, wherein deleterious substances cannot penetrate the surfaces of concrete specimens.

The crack frequency was reduced in specimens with hydrophobic coatings. The specimens without hydrophobic coatings exhibited a significant reduction in their mass percentages. As shown in Fig. 10, a group of specimens with a higher number of crack frequencies exhibited a higher percentage of mass reduction. A higher crack frequency will allow more passage of deteriorating 
agents to the surface of the concrete and lead to imminent deterioration of the steel rebars. The above results were verified in a study conducted by Arya et al., when the crack frequency decreased the corrosion level of the steel reinforcement and its mass loss also decreased [8]. Thus, polyurethane helps to reduce the corrosion rates and number of crack frequencies in the sample specimens.

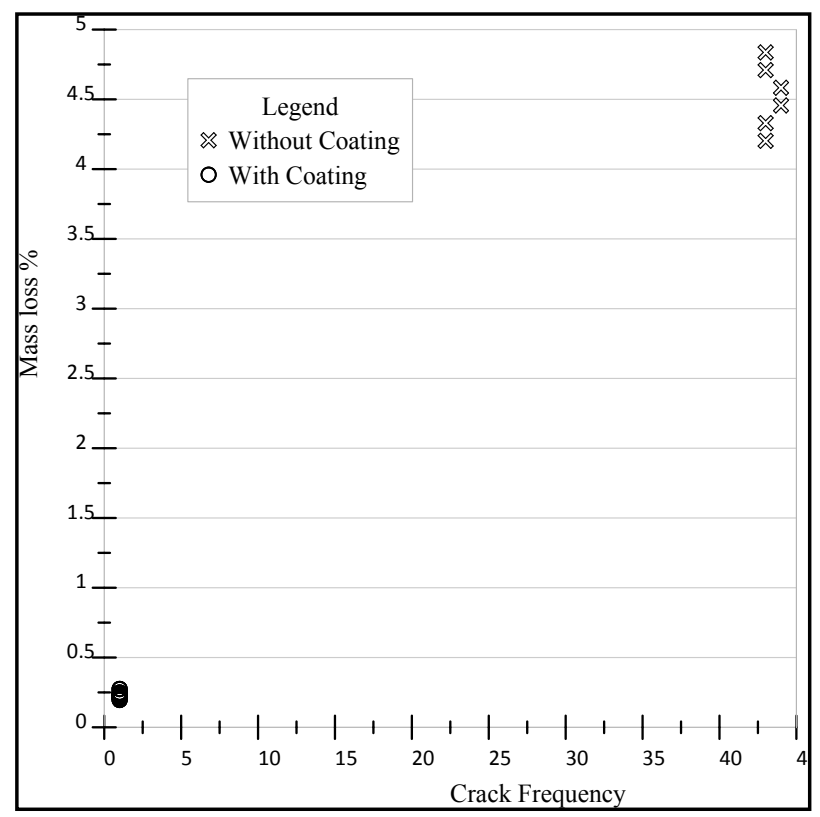

Figure 10. Correlation of Crack Frequency to Mass Loss (\%)

\subsubsection{Crack Width}

Crack width is a practical parameter for the design and assessment of reinforced concrete structures [21, 41]. It is an essential parameter for determining the durability of concrete structures $[6,40]$. To create a better-informed decision regarding the repair of structures due to concrete cracking, it is important to analyze the increase in crack width over time [22, 33].

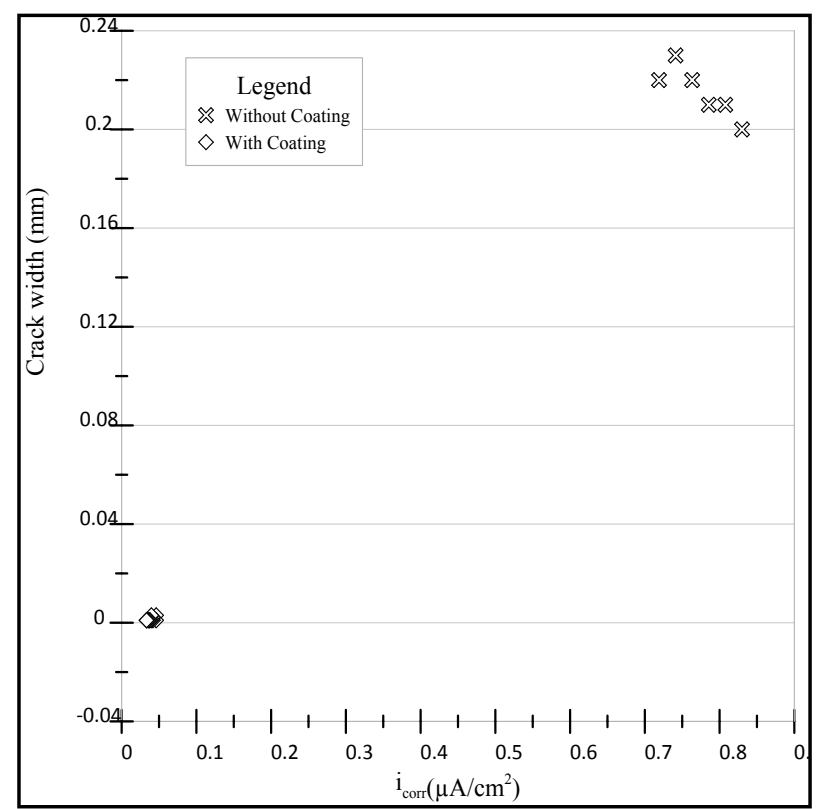

Figure 11. Correlation of corrosion rate and crack widths

The corrosion rates of specimens with the same diameter reinforcement were not constant; thus, several cracks that formed had different crack widths or openings. As shown in Fig. 11, the group of specimens without hydrophobic coatings had higher corrosion rates and wider crack widths, whereas the specimens with hydrophobic coatings had lower corrosion rates with narrower crack openings. Two (2) times the application of polyurethane to the surface of the concrete specimen are insufficient; thus, three (3) coating applications should be observed to make concrete impermeable.

\subsubsection{Crack Depths}

Pathways are established through crack opening for the deteriorating agents to penetrate the concrete surface. The depth of the passage formed is the depth of the cracks. The depths of the cracks formed on the concrete surface are linearly related to the amount of loss in the diameter of the steel [6].

As shown in Fig. 12, the specimen without coatings had higher corrosion rates and deeper crack depths. This provided significant deductions of the reinforcement diameters. The specimens with polyurethane coatings had lower corrosion rates and less reduction in their diameters. As confirmed by Andrade et al., a loss of only a few micrometers in its steel cross-sectional area with lower corrosion rates can induce visible cracks of $0.10 \mathrm{~mm}$ width with deeper cracks [7]. 


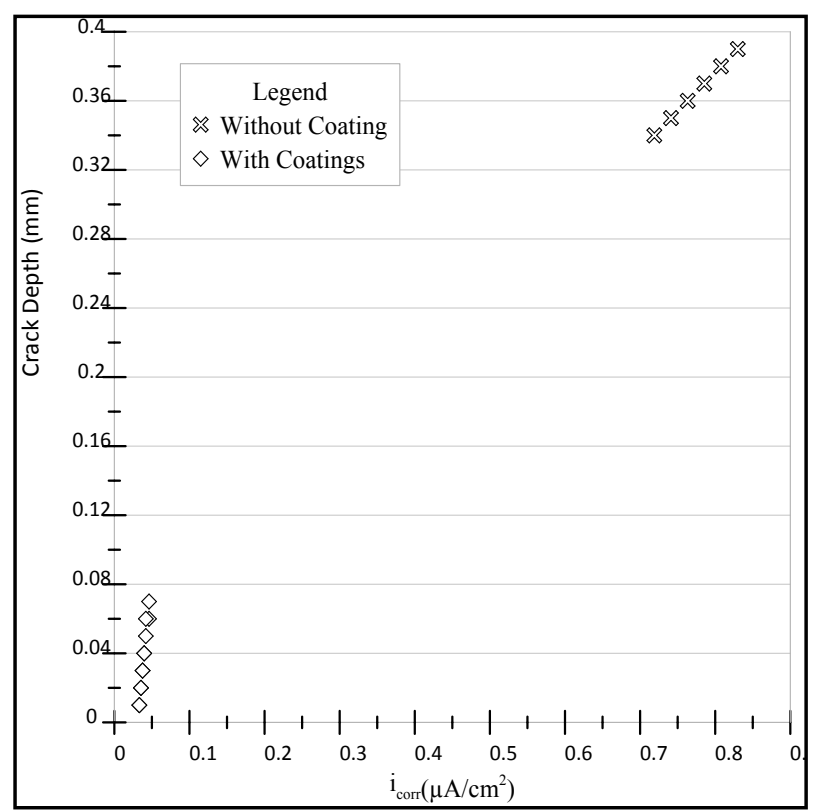

Figure 12. Correlation of Crack Depth with Corrosion Rates

\subsubsection{Time of Cracking}

Cracks were formed immediately on the surfaces of the uncoated specimens. As verified in Fig. 13, it takes only 10 days for the specimen without polyurethane coatings to crack. However, it takes longer to accelerate the development of cracks at the surface of the specimen with polyurethane coatings.

According to Chun-Qing et al., the corrosion rates significantly affect the cracking time of reinforced concrete structures. Specimens with low corrosion rates take a longer time for cracks to appear on the concrete surface [13].

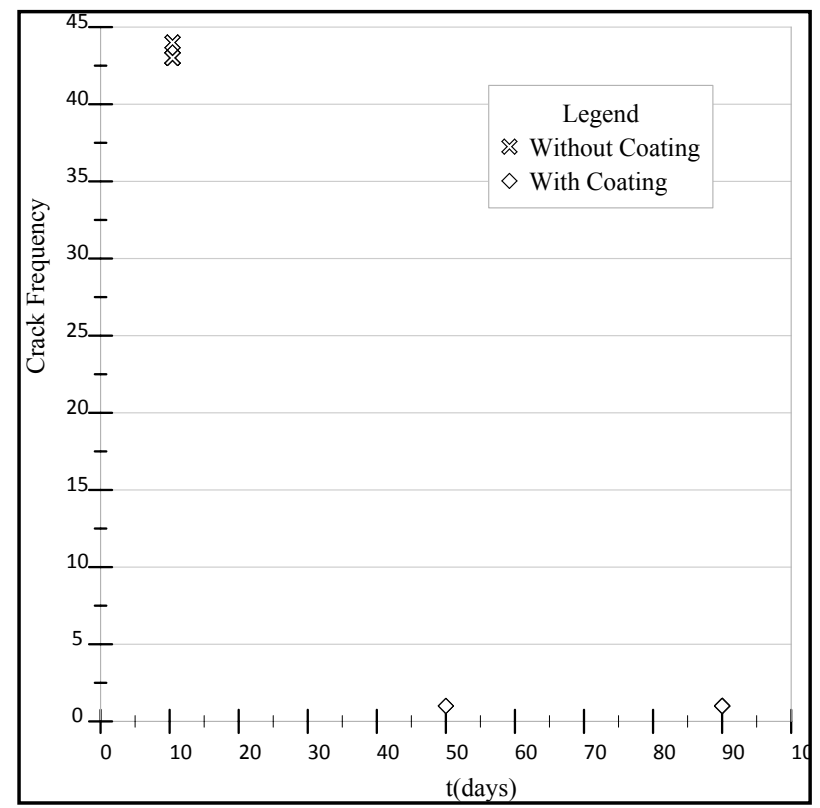

Figure 13. Influence of Crack Frequency to Time of Cracking of Concrete Specimen (days)

\subsubsection{Critical amount of corrosion}

Predicting the time of cracking induced by corrosion is an essential factor for predicting the serviceability of corroded reinforced concrete structures. The time of corrosion initiation and corrosion rates are the two factors that influence the deterioration of structures exposed to an aggressive marine environment. The two deterioration factors are also related to the residual capacity of the corroded structures.

A critical amount of corrosion $\mathrm{Q}_{\mathrm{cr}}$ is the weight per square unit of rust that has formed from the decomposition of the steel rebars due to the deteriorating agent, which leads to the formation of hairline cracks on the cover surface of concrete, which embeds the steel reinforcement. It is the amount of corrosion products that add up to the original volume of the steel and cause expansions on its concrete surfaces [8]. The critical

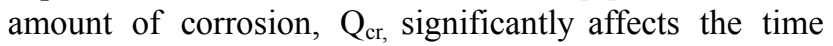
required for the specimen to crack. An increase in the amount of corrosion that accumulates in a certain period causes cracking and eventually spalling of the concrete cover.

As shown in Fig. 14, the specimen without coatings had a higher amount of corrosion $\mathrm{Q}_{\mathrm{cr}}$, which accumulated in a short period of acceleration. A specimen with polyurethane coatings has a lower amount of corrosion $\mathrm{Q}_{\mathrm{cr}}$, and it takes a longer period to accumulate a critical amount of corrosion.

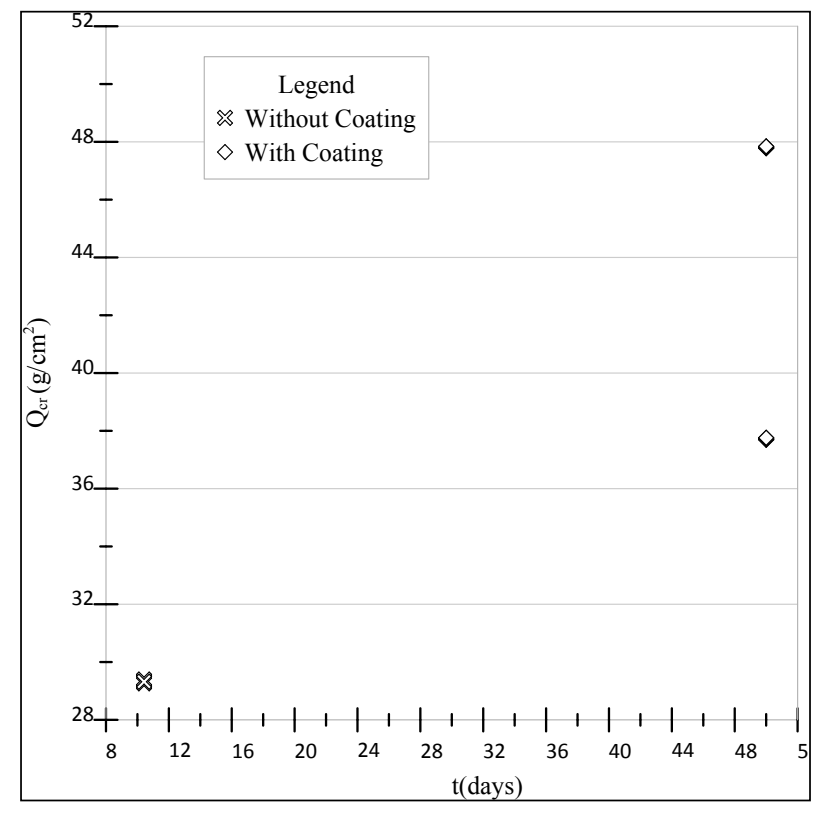

Figure 14. Influence of amount of corrosion to time of cracking

3.5.6. Corrosion level to produce the first crack 


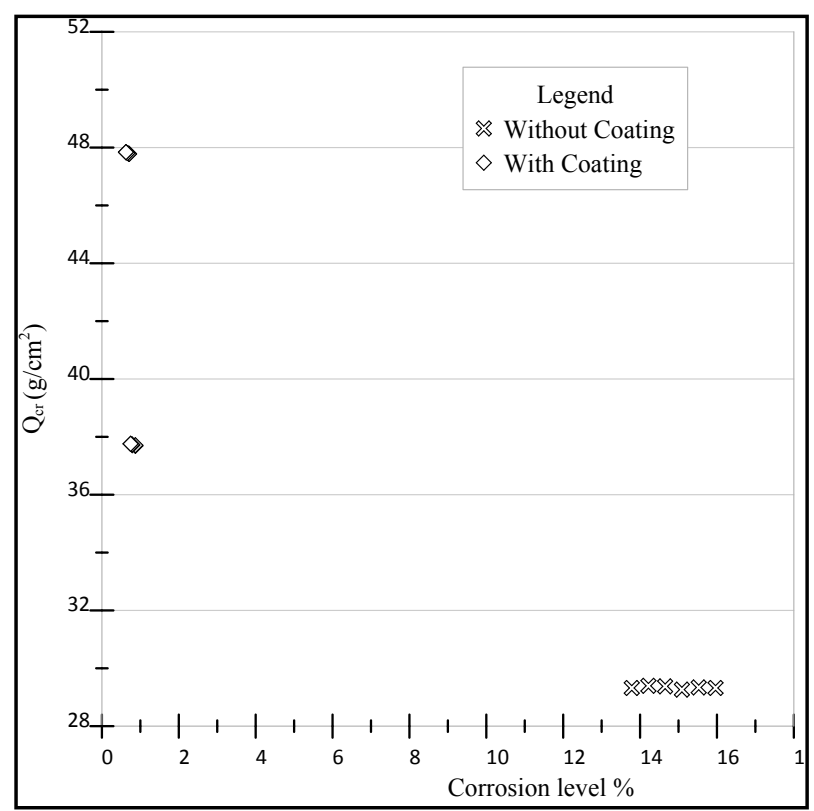

Figure 15. Corrosion level vs. Critical amount of corrosion

Fig 15 shows the correlation between the corrosion level and the critical amount of corrosion. The amount of corrosion is a crucial factor that can be used to predict the residual safety and serviceability of reinforced concrete structures. The critical amount of corrosion products is important for assessing the serviceability of corroded reinforcement steel rebars. It is according to Ravindrarajah and Ong, that growth of 0.10 to $0.20 \mathrm{~mm}$ thick corrosion products was sufficient to develop cracks on the surface of the concrete [29]. In addition, according to Andrade et al., even a minimal reduction in rebar cross-sectional area can induce cracks with $0.10 \mathrm{~mm}$ width [4]. It was further verified from the experiments that the critical amount of corrosion of the group of specimens without coatings was higher with higher corrosion levels. The specimens with hydrophobic coatings exhibited lower corrosion levels and a critical amount of corrosion.

\section{Conclusions}

- The application of polyurethane coatings to concrete surfaces is a cost-effective and feasible solution for protecting reinforced concrete structures.

- The chloride permeability of the specimen concrete mortar coated with polyurethane coatings was negligible, whereas that of the uncoated concrete specimens was low.

- Specimen with Polyurethane coatings shows no deterioration. The mortar is intact.

- The water absorption of the coated specimens is low compared with uncoated specimens.

- The specimen without coatings had a larger weight reduction, while the specimen with polyurethane coatings had a lower percent weight reduction, considering acid penetration.

- The crack frequency was reduced in the specimens with hydrophobic coatings. Polyurethane coatings fill all the pores of concrete specimens and make them less permeable. This concealed the external surfaces of the concrete specimens.

- The specimens without hydrophobic coatings had higher corrosion rates and wider crack widths, whereas the specimens with hydrophobic coatings had lower corrosion rates with narrower crack openings.

- A three (3) times application of polyurethane to the surface of the concrete specimen are sufficient to make concrete impermeable.

- The specimens without coatings exhibited higher corrosion rates and deeper crack depths. It has a great deal of deductions regarding its steel reinforcement diameter. Specimens with polyurethane coatings have lower corrosion rates and less reduction in their reinforcement diameters.

- It takes a shorter period of acceleration for the specimen without polyurethane to crack. It takes longer for cracks to develop on the surface of the specimen with polyurethane coatings.

- The specimen without coatings had a higher amount of corrosion $\mathrm{Q}_{\mathrm{cr}}$, which accumulated in a short period of acceleration. A specimen with polyurethane coatings has a lower amount of corrosion $\mathrm{Q}_{\mathrm{cr}}$ and it takes a longer period to accumulate a critical amount of corrosion.

- The critical amount of corrosion in the group of specimens without coatings was higher at higher corrosion levels. The specimens with hydrophobic coatings exhibited lower corrosion levels and a critical amount of corrosion.

\section{Funding}

The study was funded by ERDT-DOST in the School of Engineering at the University of San Carlos.

\section{Conflict of Interest}

The Authors declare no conflicts of interest.

\section{Acknowledgments}

The authors acknowledge the graduate scholarship funding from ERDT-DOST at the School of Engineering at the University of San Carlos. 


\section{REFERENCES}

[1] ACI Committee 211. Standard Practice for selecting Proportions for Normal, Heavyweight, and Mass Concrete ACI-211.1-91 (Reapproved 2002).

[2] Almusallam A, Khan F.M, Dulaijan S.U, and Al-Amoudi O.S.B, "Effectiveness of surface coatings in improving concrete durability," Cement \& Concrete Composites, Volume 25, Issues 4-5, Pages 473-481, May-July 2003. DOI:10.1016/S0958-9465(02)00087-2.

[3] Alonso C., Andrade C., Rodriguez J., and Diez J., "Factors controlling cracking of concrete affected by reinforcement corrosion," Materials and Structures, Volume 31(7), pp. 435-441. 1998. https://doi.org/10.1007/BF02480466.

[4] Al-Zahrani M., Al-Dulaijan S.U., Ibrahim M., Saricimen H., Sharif, F.M., "Effect of waterproofing coatings on steel reinforcement corrosion and physical properties of concrete," Cement \& Concrete Composites, Volume 24, pp. 127-137. 2002.

[5] Alonso, C., Andrade, C., Rodriguez, J., \& Diez, J. "Factors controlling the cracking of concrete affected by reinforcement corrosion." Materials and Structures, 31(7), 435-441. (2006). https://doi.org/10.1007/BF02480466

[6] Andrade C, Alonso C, and Molina F.J, "Cover cracking as a function of bar corrosion: part 1- experimental test," Materials and structures, Volume 26, No. 162, pp. 453-464, 1993. https://doi.org/10.1007/BF02472805.

[7] Andrade C., Castellote M., Alonso C., Gonzalez C., "Relation between colorimetric chloride penetration depth and charge passed in migration tests of the type of standard ASTM C1201-91," Cement Concrete Research, Vol. 29, Issue 3, pp. 417-421. March 1999. https://doi.org/10.1016/ S0008-8846(98)00226-9.

[8] Arya C., and Ofori-Darko F., "Influence of crack frequency on reinforcement corrosion in concrete," Cement and Concrete Research, Vol. 26, Issue 3, pp. 345-353. https://doi.org/10.1016/S0008-8846(96)85022-8.

[9] Attiogbe E., Rizkalla K., Sami H., "Response of Concrete to Sulfuric Acid Attack," ACI Materials Journal. NovemberDecember 1988.

[10] Aurora Martínez-Loaiza, María Teresa Sánchez-Medrano, "Variations in Mass and Resistance Due to Accelerated Weathering Effects in Concrete Specimens Used in Low-income Housing," Civil Engineering and Architecture, Vol. 8, No. 5, pp. 1039 - 1046, 2020. DOI: $10.13189 /$ cea.2020.080530.

[11] Bakharev T., "Resistance of geopolymer materials to acid attack," Cement and Concrete Research, Volume 35, Issue 4 , pp. 658-670. April 2005. https://doi.org/10.1016/j.cemconr es.2004.06.005.

[12] Balagopal V, Viswanathan T. S, "Evaluation of Mechanical and Durability Performance of Coir Pith Ash Blended Cement Concrete," Civil Engineering and Architecture, Vol. 8, No. 5, pp. 1028 - 1038, 2020. DOI: 10.13189/cea.2020.080529.

[13] Chun-Qing, Li, R.E. Melchers, J.-j. Zheng. "Analytical model for corrosion - induced crack width in reinforced concrete structures." ACI Struct. J. 103. Pp. 479-487. (2007).

[14] Di Mundo R., Labianca C., Carbone G., and Notarnicola M., "Recent Advances in Hydrophobic and Icephobic Surface Treatments of Concrete," MDPI. Coatings 2020, 10(5), 449, May 2020. https://doi.org/10.3390/coatings 100 50449 .

[15] GCP Applied technologies, "Understanding AASHTO T277 and ASTM C1202 Rapid Chloride Permeability Test," Ontario, Canada. 2016.

[16] Gonzalez-Garcia Y., Souto R.M., "Electrochemical and structural properties of a polyurethane coating on steel substrates for corrosion protection," Corrosion Science, Vol. 49, Issue 9, pp. 3514-3526, 2007. https://doi.org/10.1016/j. corsci.2007.03.018

[17] Horiguchi K., Yamaguchi T., Maruya T., and Takewaka K., "Study on the Method of Measuring the Chloride Threshold Value of Corrosion and Estimation of the Values in Durability Design of Concrete Structures," Journal of Advanced Concrete Technology, Vol. 18, pp. 571-587, October 2929 / Copyright @ 2020 Japan Concrete Institute. doi:10.3151/jact.18.571.

[18] Iribarren J.I., Armelin E., Liesa F., Casanovas J., and Aleman C., "On the use of conducting polymers to improve the resistance against corrosion of paints based on polyurethane resins," Materials and Corrosion, Vol. 57, No. 9. 2006. DOI: 10.1002/maco.200503952.

[19] Jin, X., Tong, J., Tian, Y., \& Jin, N. "Time-varying relative displacement field on the surface of concrete cover caused by reinforcement corrosion based on DIC measurement." Construction and Building Materials, 159, 695-703. https://doi.org/10.1016/j.conbuildmat.2017.10.119

(2018).

[20] Khitab A., Anwar W., and Arshad M.T., "Predictive Models of Chloride Penetration in Concrete: An Overview," MUST Journal of Engineering and Applied Sciences MJEAS. Eng.

And Appl. Sci. February 4, 2017. doi:10.22496/mjeas2017 0103.

[21] Lei M., Lin D., Liu J., Shi C., Ma J., Yang W., and Yu X., "Modified chloride diffusion model for concrete under the coupling effect of mechanical load and chloride salt environment," AIP Advances 8,035029. 2018. https://doi.o $\mathrm{rg} / 10.1063 / 1.5027540$.

[22] Li C.Q., Zheng J.J., Lawanwisut W., and Melchers R.E., "Concrete Delamination Caused by steel reinforcement corrosion," Journal of Materials in Civil Engineering, Vol. 19, Issue 7. July 2007. https://doi.org/10.1061/(ASCE)089 9-1561(2007)19:7(591).

[23] Li F., and Yuan Y., "Effects of corrosion on bond behavior between steel strand and concrete," Construction and Building Materials, Vol. 38, pp. 413-422. January 2013. https://doi.org/10.1016/j.conbuildmat.2012.08.008.

[24] Luping T, and Nilsoon L., "Rapid determination of the chloride diffusivity in concrete by applying an electrical field,” ACI Mater Journal, Vol. 89, Issue 1, pp. 49-53. 1992. 
[25] Maljbro L., "The complete solution of Fick's second law of diffusion with time-dependent diffusion coefficient and surface concentration," Cementa AB, Lund, Sweden, pp. 127-158, 1996.

[26] Makhlouf, H.M. \& Malhas, Faris. "The effect of thick concrete cover on the maximum flexural crack width under service load." 93. 257-265. (1996).

[27] Medeiros M.H.F., Helene P., "Surface treatment of reinforced concrete in marine environment: Influence on chloride diffusion coefficient and capillary water absorption," Construction and Building Materials, Vol. 23, Issue 3, pp. 1476-1484, 2009. Doi:10.1016/j.conbuildmat.2 008.06.013.

[28] Ramesh Singh, "Corrosion Control for Offshore Structures. Chapter one-Need for the Study of Corrosion," Cathodic Protection and High Efficiency Coating, pp. 3-6, $2014 \mathrm{a}$.

[29] Ramesh Singh, "Corrosion Control for Offshore Structures. Chapter Two - Corrosion Principles and Types of Corrosion.," Cathodic Protection and High Efficiency Coating, pp. 7- 40, 2014b.

[30] Ravindrarajah R., and Ong K., "Corrosion of steel in concrete in relation to bar diameter and cover thickness," ACI-SP, Vol. 100, pp. 1667-1678, 1987.

[31] Sandberg P., "Durability of concrete in saline environment," Cementa, Pp.150. 1996.

[32] Selvaraj R., Selvaray M., Iyer S.V.K., "Studies on the evaluation of the performance of organic coatings used for the prevention of corrosion of steel rebars in concrete structures," Progress in Organic Coatings, Vol. 64, pp. 454-459, 2009. doi:10.1016/j.porgcoat.2008.08.005.

[33] Shaikh, F.U.A., "Effect of Cracking on Corrosion of Steel in Concrete," Int J Concr Struct Mater, Vol. 12, Issue 3, 2018. https://doi.org/10.1186/s40069-018-0234-y.
[34] Song L., Sun W., and Gao J., "Time dependent Chloride Diffusion Coefficient in Concrete," Journal of Wuhan University of Technology - Mater. Sci. Ed., Vol. 28. No. 2. 2013. Doi: 10.1007/s11595-013-0685-6.

[35] Stanish K., Hooton R., and Thomas M., "Testing the Chloride Penetration Resistance of Concrete: A Literature Review," FHWA Contract DTFH61-97-R-00022 "Predicti on of Chloride Penetration in Concrete", Jan. 1997.

[36] Suprenant B., "Testing for chloride permeability of concrete," Publication \# C910531. Copyright 1991, The Aberdeen Group.

[37] Swamy RN, Hamada H, Laiw J.C., "A critical evaluation of chloride penetration into concrete in marine environment," In: Conference on Corrosion and Corrosion Protection of Steel in Concrete, Sheffield, UK, 1994.

[38] Tang L., and Nilsson L.A, "Accelerated tests for chloride diffusivity and their application in prediction of chloride penetration," Contribution to MRS Fall Meeting, Boston 1995. Chalmers University of Technology, Gothenburg, Sweden.

[39] Tapan M., and Aboutaha R., "Effect of steel corrosion and loss of concrete cover on the strength of deteriorated RC columns," Construction and Building Materials, Vol. 25, Issue 5, pp. 2596-2603. 2011. https://doi.org/10.1016/j.con buildmat.2010.12.003.

[40] Tittarelli F., Mobile A., Bellezze T., "The Effect of Fly Ash on the Corrosion Behaviour of Galvanized Steel Rebars in Concrete," IOP Conference Series: Materials Science and Engineering 225, 012107. Doi:10.1088/1757-899X/225/1/ 012107.

[41] Yang S., Li K., and Li C., "Numerical determination of concrete crack width for corrosion-affected concrete structures," Computers \& Structures, Vol. 207, pp. 75-82. 2018. https://doi.org/10.1016/j.compstruc.2017.07.016. 